\title{
Transportation impacts of affordable housing: Informing development review with travel behavior analysis
}

\author{
Amanda Howell \\ Portland State University \\ ahowell@pdx.edu \\ Gregory Norton \\ Portland State University \\ gn2@pdx.edu
}

\author{
Kristina M. Currans \\ University of Arizona \\ curransk@email.arizona.edu
}

\author{
Steven Gehrke \\ Portland State University \\ sgehrke@pdx.edu
}

\begin{abstract}
Planning for affordable housing is challenged by development policies that assess transportation impacts based on methodologies that often do not distinguish between the travel patterns of residents of market-rate housing and those living in affordable units. Given the public goals of providing affordable housing in areas with good accessibility and transportation options, there is a need to reduce unnecessary costs imposed by the potential overestimation of automobile travel and its associated impacts. Thus, the primary objective of this paper is to examine and quantify the influences of urban characteristics, residential housing type, and income on metrics commonly used to assess the transportation impacts of new development, namely total home-based trips and home-based vehicle trips. Using the 20102012 California Household Travel Survey, we regressed these metrics on urban place type, regionally adjusted income, and housing type, controlling for household size, weekday travel, and home location. The results indicate significant reductions in vehicle trip making with lower incomes and increasing urbanization. These findings support more differentiation of affordable and market-rate housing in the development review process and emphasize the need for development standards to be more sensitive to the characteristics of future residents and location.
\end{abstract}

Keywords: Trip generation, affordable housing, transportation impact analysis, low-income, land use

\section{Article history:}

Received: November 24, 2016

Received in revised form:

August 24, 2017

Accepted: October 12, 2017

Available online: January 5, 2018

\section{Introduction}

The development-review process generally requires an evaluation of the anticipated additional transportation demand that new development places on the system and an assessment of fees or improvements to mitigate of these impacts. However, industry standard guidelines for assessment of travel demand are

Copyright 2018 Amanda Howell, Kristina M. Currans, Gregory Norton \& Kelly J. Clifton http://dx.doi.org/10.5198/jtlu.2018.1129

ISSN: 1938-7849 | Licensed under the Creative Commons Attribution - Noncommercial License 3.0

The Journal of Transport and Land Use is the official journal of the World Society for Transport and Land Use (WSTLUR) and is published and sponsored by the University of Minnesota Center for Transportation Studies. This paper is also published with additional sponsorship from WSTLUR. 
outlined within the Institute of Transportation Engineers (ITE) Trip Generation Handbook (Institute of Transportation Engineers, 2014) with data provided by the Trip Generation Manual (Institute of Transportation Engineers, 2012). These professional resources have been focused solely on vehicle trip rates for these traffic impact analyses.

This approach has long been criticized as having limitations regarding the insensitivity of these sources to urban contexts, socio-demographics of system users, and non-automobile transportation choices, despite the wealth of research accumulated on their importance in shaping travel behavior (Clifton, Currans, \& Muhs, 2013; Weinberger, Dock, Cohen, Rogers, \& Henson, 2015; Millard-Ball, 2015). As a result of this insensitivity, there may be undue costs placed on affordable housing projects, as methods may inaccurately estimate higher levels of vehicle use than are actually realized by residents. In addition, an overestimation of automobile demand may misdirect resources and create environments that are not supportive of the modes they do use.

There is a need to identify and analyze the extent to which these travel outcomes vary by these important characteristics. Using the 2010-2012 California Household Travel Survey, this paper explores how income, built environment measures, household size, and housing type relate to observed travel behavior, specifically in terms of trip generation (or trip frequency). The goal is to inform the current affordable housing policy debate by providing the anticipated differences in transportation outcomes between residents of affordable and market-rate units across different urban contexts. Specifically, we demonstrate how development policies may unduly penalize these projects if they do not account for the significantly lower rates of trip generation and use by their residents. Further, our analysis points to some key considerations for efficiently locating these units in areas that provide greater transportation choices.

The remainder of the paper is organized as follows. The next section of the paper provides a review of the policy context and the literature, followed by a description of the methodological approach. The results of two multivariate models examining travel outcomes are described in the fourth section, and finally a discussion of the trends in the conclusion.

\section{$2 \quad$ Background}

Households of limited means have fewer choices in both where they can afford to live and how they can travel. Nationally, the share of households residing in rental housing rose from 31\% in 2005 to $37 \%$ in 2015, while household incomes receded back to 1995 levels (Joint Center for Housing Studies, 2015). The current supply of affordable rental housing has not matched this growing demand, as the rental vacancy rate has steadily declined while the rental market has tightened (Steffen et al., 2015). Most developers cannot build new affordable housing stock for low-income households without subsidies to close the growing gap between their construction costs and tenants' affordable rents (Joint Center for Housing Studies, 2015). Moreover, while low-income residents of these rental units may participate in programs to ease some of the burden of increasing housing costs, they are also likely to face higher transportation costs or more limited access to employment opportunities, medical needs, and other necessities (The Center for Neighborhood Technology, 2012).

For example, income is a key determinant of auto ownership (Pucher \& Renne, 2003; Giuliano \& Dargay, 2006; Blumenberg \& Pierce, 2012). Given their limited access to personal automobiles, lowincome adults are more likely to travel regularly by public transit (Giuliano, 2005). Beyond auto ownership, Ong and Houston (2002) found public transit use for commuting and job-searching purposes corresponds with an inability of low-income adults to access a vehicle and having poor or limited local bus service. Low-income households reported the cost of transit as a larger problem than households earning a higher annual income (Giuliano, 2005). As such, low-income groups also tend to walk more 
often for transportation (Pucher \& Renne, 2003; Tal \& Handy, 2010). Travel patterns resulting from the limited set of transportation options and household needs of priority populations include fewer person trips and less distance traveled (Murakami \& Young, 1997; Pucher \& Renne, 2003).

Constructing affordable housing developments in location-efficient neighborhoods, or those with environments that support non-automobile travel options, is a strategy for improving the access of low-income residents to both work and non-work activities. Travel to destinations becomes convenient as residential densities, public transit accessibility, mixed uses, and supports for pedestrian and cycling increase and as a result, vehicle ownership and use decline (Holtzclaw, Clear, Dittmar, Goldstein, \& Haas, 2002). In a recent California-based study aimed at addressing the issue of affordable housing as a climate strategy, Newmark and Haas (2015) found low-income households are likely to reside within location-efficient areas characterized by smaller dwellings, greater transit accessibility, and lower vehicle ownership rates. Chatman (2013) suggested that higher development density, greater local access to shops and services, and less parking could induce households of all income levels to drive less.

Unfortunately, the cost to construct affordable multifamily sites within location-efficient areas is becoming exceedingly expensive. Regulatory (e.g., zoning restrictions) and financing (e.g., insufficient government subsidies) obstacles limit the ability of rental housing developers to significantly add affordable multifamily housing stock. Accordingly, several cities are currently experimenting with reduced parking requirements to offer some regulatory relief to developers (Joint Center for Housing Studies, 2015). The construction of multifamily housing with less onsite parking allows developers to build more housing units for low-income households who are less likely to own vehicles and in urban contexts where non-automotive travel is feasible (Manville, 2013). Parking construction costs reduce the affordable housing supply and result in more expensive housing since these additional costs may be passed on to renters and/or households may have to pay for a parking space regardless of auto ownership status (Rowe, Morse, Ratchford, Haas, \& Becker, 2014). Together, the impact of space devoted to parking and parking costs present two major barriers to providing persons of low-income with affordable housing options with strong regional and local access (Rogers, et al., 2016).

While the travel patterns and needs of low-income households have been documented in research, this information has yet to be incorporated into methods for reviewing the impacts of new housing development (Clifton et al., 2013; Schneider, Shafizadeh, Sperry, \& Handy, 2013; Dock et al., 2015) and builds off of research focusing on housing and commercial land uses previously completed in California (Kimley-Horn and Associates, Inc., Economic \& Planning Systems, \& Gene Bregman \& Associates, 2009; Schneider et al. 2015). The industry standards for estimating transportation impacts are the data and methods presented in the Institute of Transportation Engineers' (ITE) Trip Generation Handbook (2014); but as yet, there are no standard methods or available data to differentiate the transportation impacts of affordable housing developments (as compared to market-rate housing) across urban, suburban, or rural contexts in the U.S. This research aims to fill this gap by explicitly linking affordable housing development policies to the kinds of information, albeit limited, used in assessing transportation impacts during development review.

\section{Data and methods}

The 2010-2012 California Household Travel Survey (HTS) is used for this analysis. The survey sampled 42,431 households across all fifty-eight counties in California and participants agreed to complete a one-day travel diary, as well as provide socio-demographic and -economic information. Summaries for household-level trip making were computed from the trip segment data file by University of California, Irvine (Rindt, 2015) and provided by Caltrans as part of the HTS.

Based on our interests in linking our analysis to transportation-impact analyses, the travel outcome 
variables selected for the analysis are home-based vehicle trips and home-based person trips, all aggregated at the household level. These are commensurate with information used in state-of-the-practice trip generation analysis. Although travel behavior research has identified a large number of correlates with these travel outcomes, we limited the number and type of independent variables to mirror those factors that are available during development review stage of a project (pre-occupancy) and commonly used in transportation analyses. The independent variables include household size, dwelling type (single-family/ multifamily housing), day of the week (weekday/weekend), household income (relative to affordable housing limits) and urban context at the place of residence. We controlled for weekday versus weekend travel using a single dummy variable because of expected differences in travel patterns between those two periods. Additionally, we controlled for potential differences in the large metropolitan areas of Los Angeles and San Francisco due to variations in the regional economies, urban spatial structures, and transportation options in those places.

\section{$4 \quad$ Income qualifying limits for affordable housing programs}

Income data are categorical in the HTS. Thus, the midpoint of each income category associated with a household was used to represent its income. California's Official State Income Limits for 2016 were used to relate each household's income to the qualifying limits for housing policy programs in each household's location and to control for regional economic variations (Bates, 2016). These annual qualifying income limits are used to determine eligibility for subsidized housing programs in California and are calculated by the Department of Housing and Community Development based on the US Department of Housing and Urban Development's (HUD) specification for below-market rates. Median income for each county is determined by HUD and based upon U.S. Census Bureau's American Community Survey (ACS) data, and a four-person household represents the basis for establishing limits.

Each household was then assigned to one of these income designations: extremely low-income, very low-income, low-income, median-income, moderate-income, or above moderate-income. These designations are determined relative to the median family income for a geographic area, known as area median income (AMI) in California. Extremely low-income households are households whose incomes do not exceed $30 \%$ of the area median income; very low-income households are households whose incomes are greater than $30 \%$ of AMI and do not exceed $50 \%$ of the AMI; and low-income households are those whose incomes are greater than $51 \%$ do not exceed $80 \%$. Moderate-income levels are greater than $80 \%$ and no more than $120 \%$ of the county's AMI.

\section{$5 \quad$ Place types}

In this study, we developed a set of place typologies to capture the area-wide differences in the built environment based upon a set of indicators known to be associated with travel behavior outcomes, e.g., the "D's" (Ewing \& Cevero, 2010) and accessibility (Handy, 1993). In order to better guide urban planning policy, Caltrans developed a suite of qualitative descriptions of place types in their 2010 Smart Mobility report to illuminate the difference in urban contexts (Caltrans, 2010). We utilized the Smart Mobility place type descriptions to inform the development of statewide, quantitatively driven place types used in our analysis. We used built environment data made available by the Environmental Protection Agency's Smart Location Database (EPA's SLDB) at the Census block group geography (U.S. EPA, 2014).

To classify each location into clustered place types, a discriminant analysis was used in order to place each zone into a unique category. To simplify the method of post-hoc location classification, we categorized the built environment in each of the 23,190 Census block groups in California based on a set of six characteristics: the population, employment, and intersection density in addition to percent of 
single-family housing units and proportion of jobs within a half mile of a fixed-service transit stop or 45 minutes via auto travel. Table 1 provides the descriptive statistics for each these measures per place type.

Each block group was then classified as one of five place types based on the variation in these built environment indicators. The procedure for place type assignment began by selecting all block groups with $80 \%$ of its area in an urban area (as defined by the US Census); those block groups deemed outside of urban areas were classified as non-urban. Each of six built environment variables were then manually divided into four intervals — first using standard breaks methods (e.g., Jenks breaks, clustering analysis), followed by manual modification of segments based upon examination of its distribution spatially. This inspection was iterative and involved an examination of variation across neighborhoods using online resources (e.g., Google StreetView); regional definitions of place types, e.g., (Caltrans, 2010); and local expertise (e.g., discussions within the research team, project panel, and sponsoring agency). Each block group was then assigned a score between one and four for each of the built environment measures depending on the interval where the calculated value of the measure was situated (e.g., a block group with no jobs would be given a value of one because it was situated in the category reflecting the lowest level of employment density). Then, the average of the scores across all six built environment characteristics was calculated for each block group and was used to assign the block groups into one of the four urban place types based on this mean interval score. Table 1 provides an overview of the break values used in creating these place types while Figure 1 displays their spatial representation throughout California.

These place types were then compared with the California results of a cluster analysis at the tract level conducted by Salon (2015). Generally, the place types were similar to those constructed by Salon, indicating relatively similar results between the two methods: clustering analysis and mutually exclusive breaks.

Each household in the study was assigned a place type based upon the classification of the Census block group of their residential location. Place types are useful for understanding the immediate context in which travel takes place. However, these places do not exist in a vacuum and the larger metropolitan structure in which they reside is an important consideration when evaluating travel. For example, an area categorized as an "urban district" in San Francisco will have similar features as an area in the same category located in Los Angeles; but the larger urban structure of each metropolitan area will also exert influence on travel choices. To this end, we introduce controls at the county level to test for the additional effects of the built environment at a larger scale.

\section{Travel outcomes}

To evaluate the relationship between household-level travel outcomes (home-based vehicle trips and total home-based person trips), we regressed each of these outcomes on income, place types, dwelling type, household size, weekday/weekend travel day, and county (see Table 2 for descriptions of all these variables). Because the transportation impacts of new development are assessed by the number of dwelling units, each outcome was predicted at a household-level aggregation.

All models were estimated with a negative binomial regression to accommodate the count-based nature of these data. We controlled for the impacts of individual counties on these trips but only Los Angeles and San Francisco counties were significant. For each model, interactions between place types, income categories, dwelling types, and counties were tested, but only those interactions in the homebased vehicle trip model provided statistical significance for interpretation, and therefore, only these interactions were included. The square of household size was included to examine the diminishing effect contributed by each additional person in the household. The statistically significant income category of Refused or Unknown was included in the models to control for any bias in this group. While developing the models, the Alkaline Information Criterion (AIC) was used to determine if variables contributed 
to explaining deviance existing in the models—-models with decreasing AIC were deemed "improved."

Table 1: Descriptive statistics and interval score breaks for built environment indicators per place type

\begin{tabular}{|c|c|c|c|c|c|c|c|c|c|c|}
\hline \multirow{2}{*}{$\begin{array}{l}\text { Place Type: } \\
\text { Indicator } \\
\end{array}$} & \multicolumn{2}{|c|}{ Urban Core } & \multicolumn{2}{|c|}{ Urban District } & \multicolumn{2}{|c|}{$\begin{array}{c}\text { Urban } \\
\text { Neighborhood }\end{array}$} & \multicolumn{2}{|c|}{$\begin{array}{c}\text { Suburban } \\
\text { Neighborhood }\end{array}$} & \multicolumn{2}{|c|}{ Non- Urban } \\
\hline & Mean & SD & Mean & SD & Mean & SD & Mean & SD & Mean & SD \\
\hline Population per Acre & 67 & 48 & 42 & 25 & 27 & 14 & 11 & 8 & $<0$ & $<0$ \\
\hline Employment per Acre & 58 & 96 & 17 & 41 & 7 & 13 & 2 & 4 & $<0$ & $<0$ \\
\hline $\begin{array}{l}\text { Percent of Single-Family } \\
\text { Housing }\end{array}$ & 0.06 & 0.07 & 0.19 & 0.20 & 0.39 & 0.25 & 0.76 & 0.25 & 0.81 & 0.18 \\
\hline $\begin{array}{l}\text { Intersections per Square } \\
\text { Mile }\end{array}$ & 213 & 148 & 165 & 111 & 126 & 79 & 85 & 47 & 5 & 8 \\
\hline $\begin{array}{l}\text { Percent of Jobs in } 0.5 \text { - } \\
\text { mile of Transit Stop }\end{array}$ & 0.93 & 0.21 & 0.45 & 0.45 & 0.19 & 0.34 & 0.03 & 0.13 & 0.00 & 0.01 \\
\hline $\begin{array}{l}\text { Number of Jobs in } 45 \\
\text { Mins. of Auto Travel }\end{array}$ & 509,569 & 186,240 & 513,498 & 176,351 & 466,294 & 163,922 & 211,857 & 179,250 & 26,942 & 45,325 \\
\hline \multicolumn{11}{|c|}{ Interval Score Breaks } \\
\hline Population per Acre & \multicolumn{2}{|c|}{80} & \multicolumn{2}{|c|}{40} & \multicolumn{2}{|c|}{20} & \multicolumn{2}{|c|}{$<20$} & \multicolumn{2}{|c|}{ N/A } \\
\hline Employment per Acre & \multicolumn{2}{|c|}{100} & \multicolumn{2}{|c|}{25} & \multicolumn{2}{|c|}{10} & \multicolumn{2}{|c|}{$<10$} & \multicolumn{2}{|c|}{ N/A } \\
\hline $\begin{array}{l}\text { Percent of Single-Family } \\
\text { Housing }\end{array}$ & \multicolumn{2}{|c|}{0.15} & \multicolumn{2}{|c|}{0.50} & \multicolumn{2}{|c|}{0.75} & \multicolumn{2}{|c|}{$>0.75$} & \multicolumn{2}{|c|}{ N/A } \\
\hline $\begin{array}{l}\text { Intersections per Square } \\
\text { Mile }\end{array}$ & \multicolumn{2}{|c|}{250} & \multicolumn{2}{|c|}{175} & \multicolumn{2}{|c|}{100} & \multicolumn{2}{|c|}{$<100$} & \multicolumn{2}{|c|}{ N/A } \\
\hline $\begin{array}{l}\text { Percent of Jobs in 0.5- } \\
\text { mile of Transit Stop }\end{array}$ & \multicolumn{2}{|c|}{0.95} & \multicolumn{2}{|c|}{0.50} & \multicolumn{2}{|c|}{0.10} & \multicolumn{2}{|c|}{$<0.10$} & \multicolumn{2}{|c|}{ N/A } \\
\hline $\begin{array}{l}\text { Number of Jobs in } 45 \\
\text { Mins. of Auto Travel }\end{array}$ & \multicolumn{2}{|c|}{400,000} & \multicolumn{2}{|c|}{300,000} & \multicolumn{2}{|c|}{200,000} & $<200$ &, 000 & & A \\
\hline $\begin{array}{l}\text { Mean Interval Score } \\
\text { Break }\end{array}$ & & & & & & & 1 & & & A \\
\hline $\begin{array}{l}\text { Number of Block } \\
\text { Groups }\end{array}$ & 3 & & & & & & 17 , & & & 34 \\
\hline
\end{tabular}

Notes: Sample size (n) is 23,190 US Census block groups. 


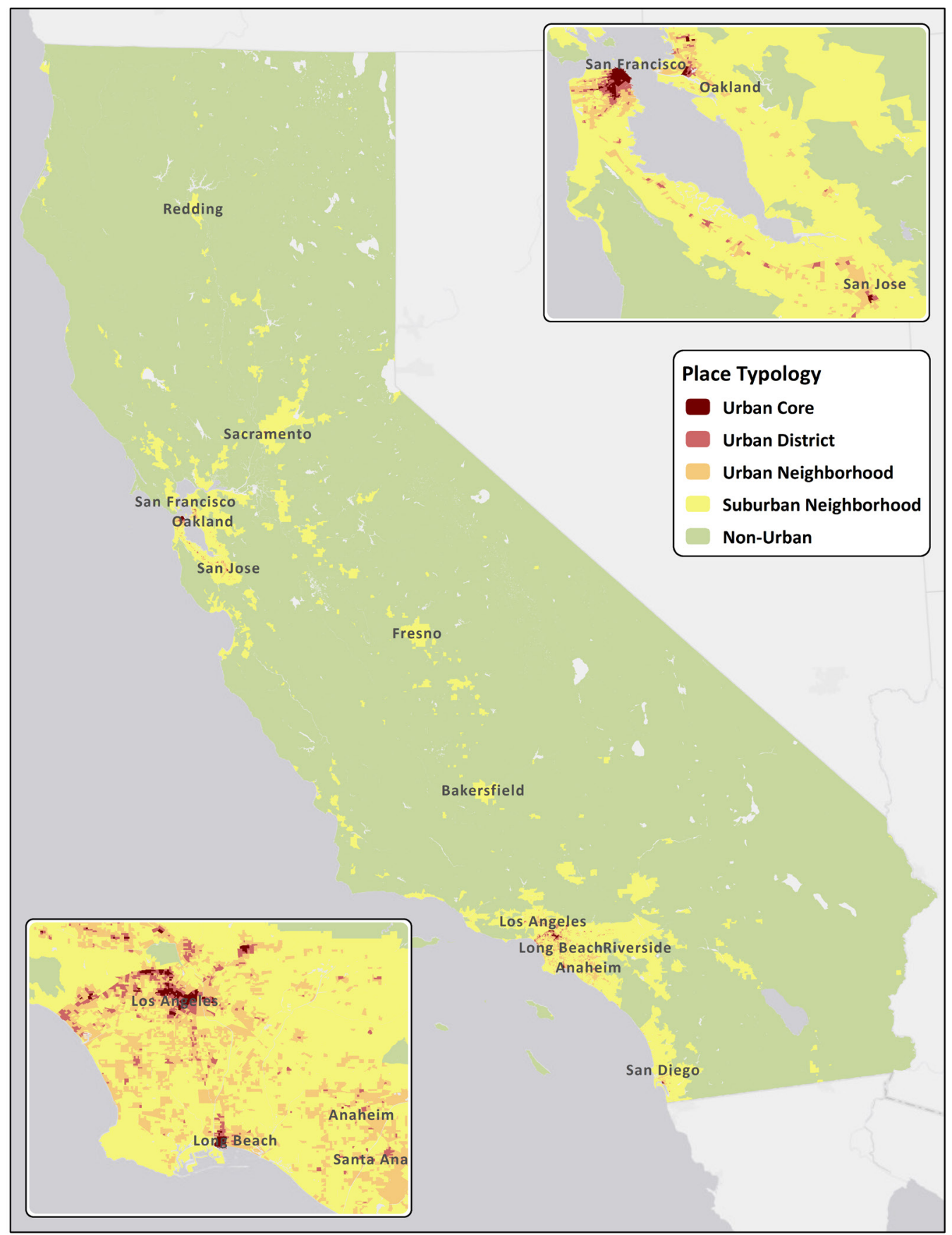

Figure 1: Place typologies applied to California 
Table 2: Description of the travel data used in model estimation

\begin{tabular}{|c|c|c|c|}
\hline Dependent Variables & Descriptions & Mean & Standard Deviation \\
\hline Home-Based Person Trips & $\begin{array}{l}\text { Count of daily home-based trips by household } \\
\text { (any mode) }\end{array}$ & 5.21 & 4.73 \\
\hline Home-Based Vehicle Trips & $\begin{array}{l}\text { Count of daily home-based vehicle trips by } \\
\text { households }\end{array}$ & 2.99 & 2.66 \\
\hline Independent Variables & Descriptions & Proportion $^{1}$ & \\
\hline \multicolumn{4}{|l|}{ County } \\
\hline Los Angeles & Respondent lives in Los Angeles County & $20 \%$ & \\
\hline San Francisco & Respondent lives in San Francisco County & $3 \%$ & \\
\hline Multifamily Housing Unit & Respondent lives in a multifamily housing unit & $15 \%$ & \\
\hline Household Size & Size of respondent's household & 2.57 & \\
\hline Household Size Squared & Size of respondent's household, squared & 8.50 & \\
\hline Weekend Travel (Fri-Sun) & Travel day was Friday, Saturday, or Sunday & $43 \%$ & \\
\hline \multicolumn{4}{|l|}{ Household Income } \\
\hline Above Moderate-Income & $>120 \%$ of the area median income & $40 \%$ & \\
\hline Moderate-Income & $81-120 \%$ of the area median income & $14 \%$ & \\
\hline Low-Income & $51-80 \%$ of the area median income & $15 \%$ & \\
\hline Very Low-Income & $31-50 \%$ of the area median income & $10 \%$ & \\
\hline Extremely Low-Income & $\leq 30 \%$ of the area median income & $12 \%$ & \\
\hline Refused or Unknown & & $9 \%$ & \\
\hline Place Type & See descriptions in the text & & \\
\hline Urban Core & & $2 \%$ & \\
\hline Urban District & & $2 \%$ & \\
\hline Urban Neighborhood & & $9 \%$ & \\
\hline Suburban Neighborhood & & $73 \%$ & \\
\hline Non-Urban & & $15 \%$ & \\
\hline Automobile Mode Share by & & Proportion & Trips (n) \\
\hline \multicolumn{4}{|l|}{ Place Type } \\
\hline Urban Core & & $41 \%$ & 3,551 \\
\hline Urban District & & $62 \%$ & 6,378 \\
\hline Urban Neighborhood & & $74 \%$ & 25,299 \\
\hline Suburban Neighborhood & & $88 \%$ & 227,271 \\
\hline Non-Urban & & $92 \%$ & 39,074 \\
\hline
\end{tabular}

Notes: ${ }^{1}$ Total households: 42,426 
Table 3: Negative binomial regression model estimates for total home-based person trips (any mode) and total homebased vehicle trips

\begin{tabular}{|c|c|c|c|c|c|c|c|c|}
\hline \multirow{3}{*}{$\begin{array}{l}\text { Travel Outcome: } \\
\text { Variable } \\
\end{array}$} & \multicolumn{4}{|c|}{ Home-Based Vehicle Trips } & \multicolumn{4}{|c|}{ Home-Based Person Trips (Any Mode } \\
\hline & \multicolumn{4}{|c|}{ Model 1} & \multicolumn{4}{|c|}{ Model 2} \\
\hline & $\mathrm{B}$ & SE & $\mathrm{p}$ & $\operatorname{Exp}(B)$ & $\mathrm{B}$ & SE & $\mathrm{p}$ & $\operatorname{Exp}(B)$ \\
\hline Intercept & -0.35 & 0.07 & 0.00 & 0.71 & 0.37 & 0.04 & 0.00 & 1.44 \\
\hline \multicolumn{9}{|l|}{ County } \\
\hline San Francisco & -0.25 & 0.04 & 0.00 & 0.77 & 0.04 & 0.03 & 0.19 & 1.04 \\
\hline Los Angeles & 0.43 & 0.10 & 0.00 & 1.53 & -0.01 & 0.01 & 0.21 & 0.99 \\
\hline Multifamily Housing Unit & -0.17 & 0.01 & 0.00 & 0.84 & 0.00 & 0.01 & 0.94 & 1.00 \\
\hline Household Size & 0.53 & 0.01 & 0.00 & 1.70 & 0.70 & 0.01 & 0.00 & 2.02 \\
\hline Household Size Squared & -0.05 & 0.00 & 0.00 & 0.96 & -0.05 & 0.00 & 0.00 & 0.95 \\
\hline Weekend Travel (Fri-Sun) & -0.18 & 0.01 & 0.00 & 0.83 & -0.09 & 0.01 & 0.00 & 0.91 \\
\hline \multicolumn{9}{|l|}{ Household Income } \\
\hline Above Moderate-Income & (base) & & & & (base) & & & \\
\hline Moderate-Income & -0.09 & 0.01 & 0.00 & 0.92 & -0.07 & 0.01 & 0.00 & 0.93 \\
\hline Low-Income & -0.16 & 0.01 & 0.00 & 0.85 & -0.12 & 0.01 & 0.00 & 0.89 \\
\hline Very Low-Income & -0.34 & 0.02 & 0.00 & 0.71 & -0.21 & 0.01 & 0.00 & 0.81 \\
\hline Extremely Low-Income & -0.60 & 0.02 & 0.00 & 0.55 & -0.23 & 0.01 & 0.00 & 0.79 \\
\hline Refused or Unknown & -0.19 & 0.02 & 0.00 & 0.82 & -0.14 & 0.01 & 0.00 & 0.87 \\
\hline \multicolumn{9}{|l|}{ Place Type } \\
\hline Urban Core & (base) & & & & (base) & & & \\
\hline Urban District & 0.47 & 0.08 & 0.00 & 1.60 & -0.01 & 0.04 & 0.73 & 0.99 \\
\hline Urban Neighborhood & 0.64 & 0.07 & 0.00 & 1.90 & -0.03 & 0.04 & 0.36 & 0.97 \\
\hline Suburban Neighborhood & 0.69 & 0.07 & 0.00 & 2.00 & -0.08 & 0.04 & 0.03 & 0.92 \\
\hline Non-Urban & 0.52 & 0.07 & 0.00 & 1.69 & -0.28 & 0.04 & 0.00 & 0.75 \\
\hline \multicolumn{9}{|l|}{ Interaction Variable } \\
\hline \multicolumn{9}{|l|}{ Los Angeles County* } \\
\hline Urban District & -0.33 & 0.11 & 0.00 & 0.72 & & & & \\
\hline Urban Neighborhood & -0.42 & 0.10 & 0.00 & 0.66 & & & & \\
\hline Suburban Neighborhood & -0.41 & 0.10 & 0.00 & 0.66 & & & & \\
\hline Non-Urban & -0.49 & 0.12 & 0.00 & 0.61 & & & & \\
\hline \multicolumn{9}{|l|}{ Model Summary } \\
\hline Observations (n) & & & & 41,021 & & & & 41,021 \\
\hline Deviance & & & & $50,351.47$ & & & & $49,600.21$ \\
\hline Alkaline Information & & & & $173,521.38$ & & & & $206,792.82$ \\
\hline \multicolumn{9}{|l|}{ Criterion } \\
\hline Log Likelihood & & & & $-86,739.69$ & & & & $-103,379.41$ \\
\hline
\end{tabular}

\section{$7 \quad$ Results}

The model results are presented in Table 3. Models 1 and 2 are negative binomial models regressing home-based vehicle trips and home-based person trips respectively upon the independent variables. To interpret the effect size of the model coefficients, we examine the exponent of the coefficients, which, for both model types allows us to examine the relationship of each variable with the respective travel outcome. For example, when values of $\exp (\mathrm{B})$ are higher than one, this indicates a positive relationship between the travel outcome measures and the corresponding independent variable and vice versa.

The results show high levels of significance for nearly all of the independent variables with a few notable exceptions. The square of household size as well as the main effect are significant, in both the estimated coefficients as well as the contribution to explaining variance and deviance in the models. 
While the main effects of household size indicate a positive relationship in the models, the square of household size is negative, indicating a diminishing relationship between each additional member of the household and each outcome-potentially representing the transportation efficiencies existing in multi-member households.

As households locate farther from the urban core (treated here as a base case), they make increasing vehicle trips. As their income decreases relative to the county median, households tend to make fewer trips and are less likely to drive. Compared to their single-family housing counterparts, households that live in multifamily units make approximately $16 \%$ fewer home-based vehicle trips.

We observe a significant mediating relationship of a Los Angeles County indicator on place type for home-based vehicle trips (Model 1), suggesting a significant relationship between place types and each outcome for Los Angeles (LA) County, compared with all other counties. These results indicate households in the urban core and urban district in Los Angeles make approximately 54\% and 10\% more home-based vehicle trips than those in the same place types in other areas of the state (except San Francisco). For urban and suburban neighborhood place types, households in LA make approximately $1-2 \%$ more home-based vehicle trips compared with other areas of the state. In non-urban areas, LA households generate approximately $6 \%$ fewer trips compared to non-urban areas in the rest of the state. Households in San Francisco generally make 23\% fewer home-based vehicle trips for all place types compared to households in all other counties. Although we tested the contribution of mediating effects of San Francisco County with place types, there was not enough evidence to suggest a significant relationship.

To better illustrate the magnitude of these effects of the independent variables, the predicted travel outcome of home-based vehicle trips is shown in Table 4. The effects are shown relative to a four-person household with an income above the moderate level, living in a single-family housing unit in a suburban place (the base case). These results are also plotted against the trip data provided in the ITE Trip Generation Manual (Institute of Transportation Engineers, 2012) for Land Use Code (LUC) 220 Residential Apartment in Figure 2. This graphic illustration shows the degree of overestimation of vehicle trips when urban context and resident incomes are not included.

There have been recent advances in the way that we assess the transportation impacts of new development. Many cities are moving away from reliance solely on vehicle trip data provided by ITE's Trip Generation Manual and collecting new multimodal data for a variety of land uses. In the latest edition of the Trip Generation Manual (9th edition), recommended practice is to start with assessment of the person trips generated by a development and then estimate how those trips are distributed across various modes. For this reason, we estimate models of home-based person trips in Table 3, Model 2.

The most notable result for the person trip estimation is that they appear to be less sensitive to place type than vehicle trips. Here, the parameter estimates for urban district and urban neighborhood are not significantly different from urban core (the base case). Suburban and rural places have significantly different and decreasing impacts on person trips. This is somewhat consistent with the notion put forth by ITE and others that residential person trips should be less variable by urban place type (Currans, 2017; Institute of Transportation Engineers, 2014), unlike the distribution of trips across various modes (including vehicle trips). This consistency across urban areas may be due to people substituting vehicle trips for walk, bike, and transit trips in more urban areas. Home-based person trip frequencies are also sensitive to income, with trip rates decreasing as income decreases. This suggests that although person trip rates may be a better starting point for evaluating site-level trip generation, the methods for evaluating transportation impacts should still consider socioeconomics of trip makers in the analysis. 
Table 4: Predicted home-based vehicle trips (Model 1) relative to base case scenario

\begin{tabular}{lccccc}
\hline Income Category & Non-Urban & $\begin{array}{c}\text { Suburban } \\
\text { Neighborhood }\end{array}$ & $\begin{array}{c}\text { Urban } \\
\text { Neighborhood }\end{array}$ & Urban District & Urban Core \\
\hline Single-Family Dwellings & & & & & \\
\hline Extremely Low-Income & $46 \%$ & $55 \%$ & $52 \%$ & $44 \%$ & $27 \%$ \\
Very Low-Income & $60 \%$ & $71 \%$ & $67 \%$ & $56 \%$ & $35 \%$ \\
Low-Income & $72 \%$ & $85 \%$ & $81 \%$ & $68 \%$ & $42 \%$ \\
Median/Moderate-Income & $77 \%$ & $92 \%$ & $87 \%$ & $73 \%$ & $46 \%$ \\
Above Moderate-Income & $84 \%$ & $\mathbf{1 0 0} \%$ & $95 \%$ & $80 \%$ & $50 \%$ \\
\hline Multifamily Dwellings & & & & & $23 \%$ \\
Extremely Low-Income & $39 \%$ & $46 \%$ & $44 \%$ & $37 \%$ & $30 \%$ \\
Very Low-Income & $50 \%$ & $60 \%$ & $57 \%$ & $47 \%$ & $36 \%$ \\
Low-Income & $60 \%$ & $71 \%$ & $68 \%$ & $57 \%$ & $38 \%$ \\
Median/Moderate-Income & $65 \%$ & $77 \%$ & $73 \%$ & $61 \%$ & $42 \%$ \\
Above Moderate-Income & $71 \%$ & $84 \%$ & $80 \%$ & $67 \%$ & \\
\hline
\end{tabular}

\section{Residential Apartment (LUC 220) Weekday Demand}

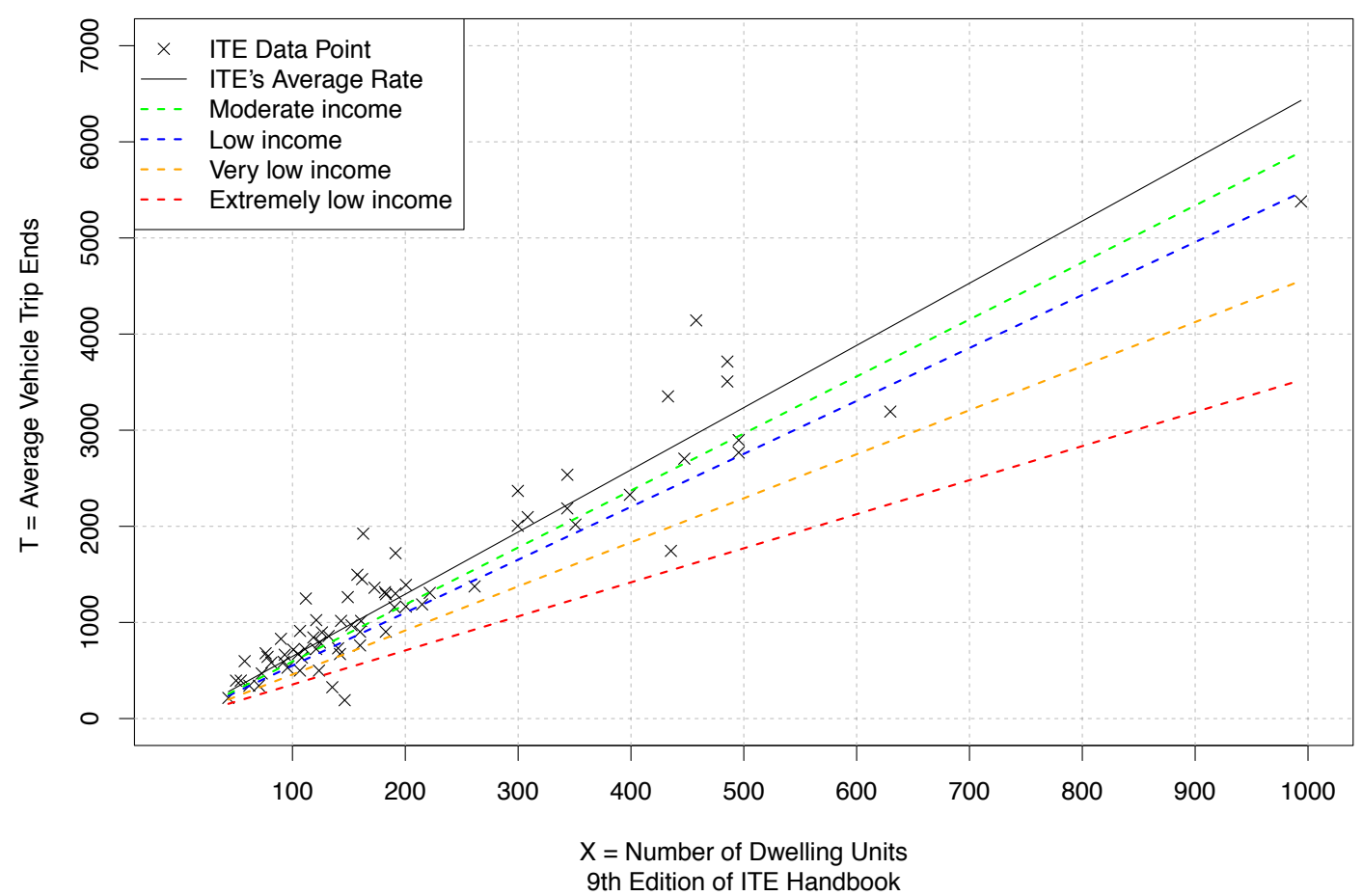

Figure 2: ITE residential apartment (LUC 220) weekday vehicle trips compared to home-based vehicle trip estimates from Model 1

\section{Implications for affordable housing development}

Many impact fee rates are developed using methodologies based upon vehicle trip estimates from ITE. If these rates are not sensitive to the issues we have been discussing - urban context and socioeconomicsthey assume that all housing development will have same impact. Some fee structures fail to distinguish 
between multifamily and single-family development and assess the same fees on all residential development. To further demonstrate the implications of these shortcomings on development costs, we extend this analysis to consider the impact fees in two case study areas-Sacramento and Pasadena, California. We obtained the most recent impact fees for these locations (City of Sacramento, 2017; City of Pasadena, 2015) and adjusted them relative to the differences in travel outcomes by income and place type using the comparisons from Table 4. Table 5 shows the amount that each unit would be over-assessed based upon the relative differences in travel impact for the location and income of residents.

We did not control for any programs, discounts, or overlay zones that these jurisdictions may have in place to reduce fees for affordable housing or developments that are efficiently located with respect to transportation options. This exercise is strictly meant as an example to illustrate the potential additional costs that may be incurred by developers when impact analysis fails to control for differences in travel by income and location.

When one considers that most affordable housing development is multifamily and thus has many units per development, these errors can accumulate and have a marked impact on cost. For example, a developer of a 50-unit affordable apartment building targeted for residents in the low-income category in an Urban District neighborhood in Pasadena would be overcharged \$59,238 in transportation impact fees. That same development in Sacramento would be overcharged \$13,353. This number is lower because Sacramento has different rates for single-family and multifamily housing; thus, accounting explicitly for some of the travel differences between residents of different dwelling types which is corroborated by our analysis. These are not insignificant amounts in a project pro forma particularly given that fees are assessed for other utilities and services beyond transportation.

\section{Discussion and conclusion}

With an interest in contributing to affordable housing development policies, this analysis examined and quantified the relative influences of urban place type, residential dwelling type, and income on the travel outcomes that are most relevant in evaluating the transportation impacts of new developments. These results show significant differences in these travel outcomes between income groups and a strong association with place type, as well as contribute to understanding the interaction effects between the two. This strongly suggests that applying traditional methods and data to evaluate the transportation impacts of affordable housing developments will overestimate vehicle use and likely result in excessive fees and unwarranted mitigations.

The significant mediating relationship of LA County on place type also indicates that there is something about the relationship between residents and the built environment that results in significantly different home-based vehicle trips, even with a similar built environment. This may indicate that metropolitan structure or regional accessibility should be considered in addition to the local contextual variables. Another possible interpretation may have to do with the variation existing in categorical definitions of place- a common simplification of continuous, highly correlated variables to derive something more easily applied and assessed in practice. Either way, these results suggest that aggregating nationally collected data without providing more detailed contextual information-e.g., city or county, continuous built environment measures - may result in severe over- or under-estimation of behavior due to regional differences in how residents interact with similar built environments.

This analysis is not without limitations. First, our analysis was not conducted with explicit data from residents of affordable housing. Rather, we used income designations to identify households that would qualify to live in affordable housing in their area and discriminated by dwelling type. As a result, our conclusions may overstate the trip making differences because residents of affordable housing may have lower housing costs than similarly situated households living in market-rate housing and thus may 
have more resources to devote to activities and travel.

Second, our models are not intended to be sensitive to the full complement of household resources, environmental conditions and policies known to impact travel behavior. Despite having access to much of this information for the households in our data, we specifically limited our choices of independent variables to those that would be available to an analyst at the time a new development is proposed and under review. In those cases, the development is not yet built and thus the specific characteristics of the household are unknown, other than the targeted income qualifying limits for the housing. Third, we do not consider the role of self-selection bias in these results. However, low-income households have more constrained choices in where to live and perhaps self-section bias considerations can be relaxed. Fourth, while we considered on-site parking requirements in our discussion we were not able to include parking information as a variable in our model. Any data collected for an alternative rate study will be submitted to the City as a part of the official record and may be used in future rate calculations. The relationship between on-site parking requirements, vehicle ownership and trip generation warrants additional study. Finally, the development of place types was based upon the context of California and thus, may not fully represent the environments in other locations. Regardless, the findings here offer important direction for housing and transportation policy in the United States more broadly.

The contribution of the models estimated in this paper is that they are a) sensitive to regionally adjusted household incomes and the characteristics of the proposed sites, and b) based upon the observed travel behavior of residents, rather than merely vehicle counts. Therefore, using these results to estimate the travel outcomes for new housing developments may provide more robust estimates than the existing tools available today. These results also punctuate the need to understand how commonly used trip generation data vary from one region to the next. Without detailed information about how ITE's rates developed from sources across the nation were derived (e.g., urban and social context), application of these methods in urban areas may place additional burden on low-income housing developers and the corresponding residents. 
Table 5: Amount of overassessment of impact fees relative to travel impacts

\begin{tabular}{|c|c|c|c|c|}
\hline \multicolumn{5}{|l|}{ City of Sacramento } \\
\hline \multirow[t]{3}{*}{ Income Category } & Suburban & Urban & Urban District & Urban Core \\
\hline & Neighborhood & Neighborhood & & \\
\hline & Over-assessment & Over-assessment & Over-assessment & Over-assessment \\
\hline \multicolumn{5}{|c|}{ Single-Family Dwellings - Transportation impact fee of $\$ 1,182.00$ per unit } \\
\hline Extremely Low-Income & $\$ 533$ & $\$ 566$ & $\$ 665$ & $\$ 858$ \\
\hline Very Low-Income & $\$ 344$ & $\$ 387$ & $\$ 515$ & $\$ 764$ \\
\hline Low-Income & $\$ 178$ & $\$ 230$ & $\$ 382$ & $\$ 681$ \\
\hline Median/Moderate-Income & $\$ 99$ & $\$ 154$ & $\$ 319$ & $\$ 641$ \\
\hline Above Moderate-Income & $\$ 0$ & $\$ 60$ & $\$ 240$ & $\$ 592$ \\
\hline \multicolumn{5}{|c|}{ Multifamily Dwellings - Transportation impact fee of $\$ 827.00$ per unit } \\
\hline Extremely Low-Income & $\$ 446$ & $\$ 465$ & $\$ 523$ & $\$ 636$ \\
\hline Very Low-Income & $\$ 334$ & $\$ 360$ & $\$ 434$ & $\$ 581$ \\
\hline Low-Income & $\$ 237$ & $\$ 267$ & $\$ 357$ & $\$ 532$ \\
\hline Median/Moderate-Income & $\$ 190$ & $\$ 222$ & $\$ 319$ & $\$ 509$ \\
\hline Above Moderate-Income & $\$ 132$ & $\$ 167$ & $\$ 273$ & $\$ 480$ \\
\hline \multicolumn{5}{|l|}{ City of Pasadena } \\
\hline \multirow[t]{4}{*}{ Income Category } & Suburban & Urban & Urban District & Urban Core \\
\hline & Neighborhood & Neighborhood & & \\
\hline & Over-assessment & Over-assessment & Over-assessment & Over-assessment \\
\hline & per unit & per unit & per unit & per unit \\
\hline \multicolumn{5}{|c|}{ Single-Family Dwellings - Impact fee of $\$ 2,747.20$ per residential unit } \\
\hline Extremely Low-Income & $\$ 1,240$ & $\$ 1,317$ & $\$ 1,546$ & $\$ 1,994$ \\
\hline Very Low-Income & $\$ 801$ & $\$ 900$ & $\$ 1,196$ & $\$ 1,775$ \\
\hline Low-Income & $\$ 415$ & $\$ 534$ & $\$ 888$ & $\$ 1,582$ \\
\hline Median/Moderate-Income & $\$ 229$ & $\$ 358$ & $\$ 741$ & $\$ 1,489$ \\
\hline Above Moderate-Income & $\$ 0$ & $\$ 140$ & $\$ 558$ & $\$ 1,375$ \\
\hline \multicolumn{5}{|c|}{ Multifamily Dwellings - Impact fee of $\$ 2,747.20$ per residential unit } \\
\hline Extremely Low-Income & $\$ 1,480$ & $\$ 1,545$ & $\$ 1,737$ & $\$ 2,114$ \\
\hline Very Low-Income & $\$ 1,111$ & $\$ 1,195$ & $\$ 1,443$ & $\$ 1,930$ \\
\hline Low-Income & $\$ 787$ & $\$ 887$ & $\$ 1,185$ & $\$ 1,768$ \\
\hline Median/Moderate-Income & $\$ 631$ & $\$ 739$ & $\$ 1,061$ & $\$ 1,690$ \\
\hline Above Moderate-Income & $\$ 438$ & $\$ 556$ & $\$ 907$ & $\$ 1,594$ \\
\hline
\end{tabular}

\section{Acknowledgements}

This research has been sponsored by Caltrans under contract number 65A0564. Additionally, Caltrans provided additional support commenting on the research design and providing access to these data. Dr. Currans would like to thank the National Institute of Transportation and Communities Graduate Fellowship and the D.D. Eisenhower Graduate Fellowship Program for providing additional funding under contract numbers 1000 and DTFH6416G00057, respectively. 


\section{References}

Bates, L. (2016). State income limits for 2016. Sacramento, CA: Department of Housing and Community Development, Division of Housing Policy Development. Retrieved from http://www.hcd. ca.gov/housing-policy-development/housing-resource-center/reports/state/inc2k16.pdf

Blumenberg, E., \& Pierce, G. (2012). Automobile ownership and travel by the poor: Evidence from the 2009 National Household Travel Survey. Transportation Research Record, 2320(1), 28-36. doi: $10.3141 / 2320-04$

Caltrans. (2010). Smart mobility 2010: A call to action for the new decade. Sacramento, CA: Caltrans.

Chatman, D. G. (2013). Does TOD need the T? Journal of the American Planning Association, 79(1), 17-31. doi:10.1080/01944363.2013.791008

City of Pasadena Permit Center. (2015). Miscellaneous fees and charges. Retrieved from https://ww5. cityofpasadena.net/planning/wp-content/uploads/sites/56/2017/08/Miscellaneous-Permit-Fees.pdf

City of Sacramento Community Development Department. (2017). Sacramento Transportation Authority STA fee table. Retrieved from http://www.cityofsacramento.org/online-services/ FeeChargeSearch?cu_fee_id=5669

Clifton, K. J., Currans, K. M., \& Muhs, C. D. (2013). Evolving the Institute of Transportation Engineers trip generation handbook: A proposal for collecting multi-modal, multi-context, establishment-level data. Transportation Research Record, 2344(2), 107-117.

Currans, K. M. (2017). Issues in urban trip generation. Portland, Oregon: Portland State University.

Dock, S., Cohen, L., Rogers, J. D., Henson, J., Weinberger, R., Schrieber, J., \& Ricks, K. (2015). Methodology to gather multimodal urban trip generation data. Paper presented at the Annual Meeting of the Transportation Research Board, Washington, DC.

Ewing, R., \& Cevero, R. (2010). Travel and the built environment: A meta-analysis. Journal of the American Planning Association, 76(3), 265-294.

Giuliano, G. (2005). Low income, public transit, and mobility. Transportation Research Record, 1927(1), $63-70$.

Giuliano, G., \& Dargay, J. (2006). Car ownership, travel and land use: A comparison of the U.S. and Great Britain. Transportation Research Part A, 4O(1), 106-124.

Handy, S. (1993). Regional versus local accessibility: Implications for nonwork travel. Transportation Research Record, 1400, 58-66.

Holtzclaw, J., Clear, R., Dittmar, H., Goldstein, D., \& Haas, P. (2002). Location efficiency: Neighborhood and socioeconomic characteristics determine auto ownership and use-Studies in Chicago, Los Angeles and San Francisco. Transportation Planning and Technology, 25(1), 1-27. doi:10.1080/03081060290032033

Institute of Transportation Engineers. (2012). Trip generation manual (9th ed.). Washington, DC: Institute of Transportation Engineers.

Institute of Transportation Engineers. (2014). Trip generation handbook, 3rd Edition: An ITE recommended practice. Washington, DC: Institute of Transportation Engineers.

Joint Center for Housing Studies. (2015). America's rental housing: Expanding options for diverse and growing demand. Cambridge, MA: Harvard University.

Kimley-Horn and Associates, Inc., Economic \& Planning Systems, \& Gene Bregman \& Associates. (2009). Trip-generation rates for urban infill land uses in California: Phase 2, data collection. Sacramento, CA: California Department of Transportation. Retrieved from http://www.dot.ca.gov/ research/researchreports/reports/2009/final_summary_report-calif._infill_trip-generation_rates_ study_july_2009.pdf 
Manville, M. (2013). Parking requirements and housing development. Journal of the American Planning Association, 79(1), 49-66. doi:10.1080/01944363.2013.785346

Millard-Ball, A. (2015). Phantom trips: Overestimating the traffic impacts of new development. Journal of Transport and Land Use, 8(1), 1-19.

Murakami, E., \& Young, J. (1997). Daily travel by persons with low income. Paper presented at the National Person Travel Survey Symposium, Bethesda, MD.

Newmark, G. L., \& Haas, P. M. (2015, December 16). Income, location efficiency, and VMT: Affordable housing as a climate strategy. Retrieved from http://www.cnt.org/publications/income-locationefficiency-and-vmt-affordable-housing-as-a-climate-strategy

Ong, P. M., \& Houston, D. (2002). Transit, employment and women on welfare. Urban Geography, 23(4), 344-364.

Pucher, J., \& Renne, J. L. (2003). Socioeconomics of urban travel: Evidence from the 2001 NHTS. Transportation Quarterly, 57(3), 49-77.

Rindt, C. (2015). How to create the linked trip table. Irvine, California: University of California, Irvine, for Caltrans.

Rogers, J., Emerine, D., Haas, P., Jackson, D., Kauffmann, P., Rybeck, R., \& Westrom, R. (2016). Estimating parking utilization in multi-family residential buildings in Washington, DC. Paper presented at the Annual Meeting of the Transportation Research Board, Washington, DC.

Rowe, D., Morse, S., Ratchford, C., Haas, P., \& Becker, S. (2014). Modeling of multifamily residential parking use in King County, Washington. Transportation Research Record, 2469(1), 57-64. doi:10.3141/2469-07

Salon, D. (2015). Heterogeneity in the relationship between the built environment and driving: Focus on neighborhood type and travel purpose. Research in Transportation Economics, 52(1), 34-45.

Schneider, R. J., Shafizadeh, K., \& Handy, S. L. (2015). Method to adjust Institute of Transportation Engineers vehicle trip-generation estimates in smart-growth areas. Journal of Transport and Land Use, 8(1), 69-83.

Schneider, R. J., Shafizadeh, K., Sperry, B. R., \& Handy, S. L. (2013). Methodology to gather multimodal trip generation data in smart-growth areas. Transportation Research Record, 2354, 68-85.

Steffen, B. L., Carter, G. R., Martin, M., Pelletiere, D., Vandenbroucke, D. A., \& Yao, Y.-G.D. (2015). Worst case housing needs: 2015 report to Congress. Washington, DC: US Department of Housing and Urban Development.

Tal, G., \& Handy, S. (2010). Travel behavior of immigrants: An analysis of the 2001 National Household Transportation Survey. Transport Policy, 17(1), 85-93.

The Center for Neighborhood Technology. (2012). Safe, decent, and affordable: Transportation costs of affordable housing in the Chicago region. Chicago, IL: The Center for Neighborhood Technology.

U.S. Environmental Protection Agency. (2014, April 10). Smart location database. Retrieved from http://www.epa.gov/smartgrowth/smartlocationdatabase.html

Weinberger, R., Dock, S., Cohen, L., Rogers, J., \& Henson, J. (2015). Predicting travel impacts of new development in America's major cities: Testing alternative trip generation models. Paper presented at the 92nd Annual Meeting of the Transportation Research Board, Washington, DC. 